\title{
Members of the Trichoderma harzianum Species Complex with Mushroom Pathogenic Potential
}

\author{
Henrietta Allaga ${ }^{1,2}{ }^{(D}$, Anuar Zhumakayev ${ }^{1,2}{ }^{\oplus}$, Rita Büchner ${ }^{1,2}$, Sándor Kocsubé ${ }^{1}$, Attila Szúcs ${ }^{1}$, \\ Csaba Vágvölgyi ${ }^{1}$, , László Kredics ${ }^{1}$ a and Lóránt Hatvani ${ }^{1, *}$ \\ 1 Department of Microbiology, Faculty of Science and Informatics, University of Szeged, Közép Fasor 52, \\ 6726 Szeged, Hungary; henrietta.allaga@gmail.com (H.A.); anuar_zhumakaev@mail.ru (A.Z.); \\ cristinagodd@gmail.com (R.B.); shigsanyi@gmail.com (S.K.); a.szunyi@gmail.com (A.S.); \\ mucor1959@gmail.com (C.V.); kredics@bio.u-szeged.hu (L.K.) \\ 2 Doctoral School of Biology, Faculty of Science and Informatics, University of Szeged, Közép Fasor 52, \\ 6726 Szeged, Hungary \\ * Correspondence: lorant.hatvani@gmail.com; Tel.: +36-62-544-849
}

check for updates

Citation: Allaga, H.; Zhumakayev, A.; Büchner, R.; Kocsubé, S.; Szúcs, A.;

Vágvölgyi, C.; Kredics, L.; Hatvani, L. Members of the Trichoderma harzianum Species Complex with Mushroom Pathogenic Potential. Agronomy 2021, 11, 2434. https://doi.org/10.3390/ agronomy11122434

Academic Editors: Jaime Carrasco and Francisco J. Gea

Received: 2 November 2021

Accepted: 26 November 2021

Published: 29 November 2021

Publisher's Note: MDPI stays neutral with regard to jurisdictional claims in published maps and institutional affiliations.

Copyright: () 2021 by the authors. Licensee MDPI, Basel, Switzerland. This article is an open access article distributed under the terms and conditions of the Creative Commons Attribution (CC BY) license (https:/ / creativecommons.org/licenses/by/ $4.0 /$ )

\begin{abstract}
Previously, severe green mould infections could be attributed mainly to Trichoderma aggressivum Samuels \& W. Gams, as well as T. pleuroti S.H. Yu \& M.S. Park and T. pleuroticola S.H. Yu \& M.S. Park in the case of Agaricus bisporus (J.E. Lange) Imbach (button mushroom) and Pleurotus ostreatus (Jacq.) P. Kumm. (oyster mushroom), respectively. The purpose of our study was the examination of green mould agents deriving from the growing facilities of button mushroom, oyster mushroom and shiitake (Lentinula edodes (Berk.) Pegler) located in various countries of Europe, and initially classified into the Trichoderma harzianum Rifai species complex (THSC). Species identification was carried out using the multilocus sequence typing analysis of the internal transcribed spacer regions, as well as translation elongation factor 1-alpha, calmodulin and RNA polymerase B subunit II gene sequences. In vitro confrontation assays were applied to test the aggressiveness of the isolates towards mushrooms, while the effect of commercial fungicides on the growth of the strains was examined by the macrodilution method. Six Trichoderma species, namely T. afroharzianum P. Chaverri, F.B. Rocha, Degenkolb \& Druzhin., T. atrobrunneum F.B. Rocha, P. Chaverri \& Jaklitsch, T. guizhouense Q.R. Li, McKenzie \& Yong Wang, T. harzianum sensu stricto, T. pollinicola F. Liu \& L. Cai and T. simmonsii P. Chaverri, F.B. Rocha, Samuels, Degenkolb \& Jaklitsch were detected in the different samples, with T. harzianum, T. pollinicola and T. simmonsii being the most aggressive. Prochloraz was found to have strong in vitro inhibitory effect on mycelial growth on most strains, however, T. simmonsii isolates showed remarkable tolerance to it. Our data suggest that T. harzianum and T. simmonsii may also be considered as potential causal agents of mushroom green mould.
\end{abstract}

Keywords: cultivated mushrooms; Agaricus bisporus; Lentinula edodes; Pleurotus ostreatus; green mould; Trichoderma harzianum species complex; fungicide susceptibility

\section{Introduction}

Complying with the rising customer demand, world mushroom production has increased more than 30-fold during the past four decades [1]. The five dominant genera, accounting for $85 \%$ of the global supply include the species Agaricus bisporus (button mushroom/champignon), Pleurotus ostreatus (oyster mushroom) and Lentinula edodes (shiitake). Numerous factors, such as water activity, the ratio of carbon and nitrogen content, temperature, humidity, $\mathrm{pH}$, luminosity, air composition, as well as the quality of growing substrate/compost and casing material play key roles in mushroom cultivation, having substantial influence on the formation and development of fruiting bodies [2,3]. In addition, mushroom yield can be severely affected by different pests including insects, mites, nematodes, viruses and bacteria, but the most serious crop losses are attributed worldwide to fungal diseases such as cobweb, dry bubble, wet bubble and particularly green mould, caused Cladobotryum spp. [4-6], 
Lecanicillium fungicola (Preuss) Zare \& W. Gams [7,8], Hypomyces perniciosus Magnus (formerly Mycogone perniciosa) [9-12], and Trichoderma spp. [13-15], respectively.

Despite the large number of Trichoderma species (T. citrinoviride Bissett, T. crassum Bissett, T. hamatum (Bonord.) Bainier, T. koningii Oudem., T. longibrachiatum Rifai, T. spirale Bissett) found in mushroom compost [16], green mould outbreaks in the cultivation of A. bisporus had been attributed initially to T. harzianum [17-19]. The most aggressive biotypes, Th2 and Th4, were subsequently introduced as the new species T. aggressivum f. europaeum and T. aggressivum f. aggressivum, causing green mould infections in European countries and North America, respectively [20]. In contrast, being the only Trichoderma species detected in green mould affected samples of compost and casing material, T. harzianum was identified as the real causal agent of a severe outbreak in Croatia [21].

Green mould outbreaks have also been reported in the cultivation of P. ostreatus worldwide. The major causal agents are known to belong to the species T. pleuroti and/or T. pleuroticola [22] in numerous countries, including Korea [22], Italy, Hungary, Romania, Canada, Iran, the Netherlands, Germany, New Zealand [23-25], Croatia [21], Poland [26], as well as Serbia and North Macedonia [15]. However, Woo et al. [27] also identified T. harzianum (later re-classified as T. pleuroticola [25]) as a common pathogen of oyster mushroom in Italy, while in Hungary and Poland T. harzianum and T. atroviride Bissett were found in high proportions in addition to T. pleuroti and T. pleuroticola [24,26].

The most relevant Trichoderma pathogens of shiitake were reported to involve T. atroviride, T. citrinoviride, T. harzianum, T. longibrachiatum, T. pseudokoningii Rifai, T. polysporum (Link) Rifai, T. cf. stramineum P. Chaverri \& Samuels, T. virens (J.H. Mill., Giddens \& A.A. Foster) Arx and Trichoderma sp. [28], as well as T. mienum Chang S. Kim, Nakagiri \& N. Maek. and T. pseudolacteum Chang S. Kim \& N. Maek. in Japan [29,30], while in Korea T. atroviride, T. citrinoviride, T. harzianum, T. polysporum, T. longibrachiatum, T. viride Pers., T. pseudogelatinosum (M. Komatsu \& Yoshim. Doi) Chang S. Kim and T. pseudostramineum (Yoshim. Doi) Chang S. Kim [31], as well as T. deliquescens (Sopp) Jaklitsch were detected [32,33]. In China, T. harzianum and T. atroviride proved to be the predominant infectious agents of shiitake preceding T. viride, T. pleuroticola, T. longibrachiatum and T. oblongisporum Bissett [34], while Cao et al. [35] identified T. oblongisporum as the cause of the disease.

One of the most widespread members of the genus Trichoderma, T. harzianum was considered initially to be an aggregate species, potentially covering a number of morphologically cryptic species with different biological characteristics [36], and currently it is recognized as the "Trichoderma harzianum species complex" (THSC) [37], containing a progressively growing number of described species [38-41]. Members of the THSC occupy a broad range of habitats worldwide, including soil, living fungi and plants as well as decaying plant material [37,38], and certain species are known as mycoparasites [42,43], which explains their frequent appearance in the growing facilities of cultivated mushrooms [15]. Among the members of the THSC, the association of T. atrobrunneum, T. simmonsii and T. guizhouense with cultivated mushrooms has been reported so far in addition to T. harzianum [44-46]. Despite the comprehensive taxonomical studies, there are still knowledge gaps to be filled in terms of the biology of "T. harzianum" [47]. Therefore, in addition to the precise species identification of THSC strains isolated from green mould-affected samples of different cultivated mushrooms and their substrates, the purpose of our research was to examine the antagonistic potential of the isolates towards their hosts, as well as the potential applicability of commercial fungicides against them as means of disease control.

\section{Materials and Methods}

In the present study, Trichoderma strains recovered from button mushroom (A. bisporus), oyster mushroom (P. ostreatus) and shiitake (L. edodes) producing facilities located in different European countries were investigated. According to the results of a preliminary, ITS sequence-based analysis, the isolates were classified into the Trichoderma harzianum species complex. The fungi were grown on potato dextrose agar (PDA) medium at $25^{\circ} \mathrm{C}$. The examined strains are listed in Table 1. 
Table 1. Trichoderma strains examined in the study.

\begin{tabular}{|c|c|c|c|c|c|c|c|}
\hline \multirow{2}{*}{ Species } & \multirow{2}{*}{ Strain Number } & \multirow{2}{*}{ Source } & \multicolumn{4}{|c|}{ GenBank Accession Numbers } & \multirow{2}{*}{ Reference } \\
\hline & & & ITS & tef1 & cal1 & $r p b 2$ & \\
\hline T. afroharzianum & SZMC 12432 & Pleurotus ostreatus, Spain & MZ754498 & MZ773449 & MZ773454 & MZ773428 & Present study \\
\hline T. afroharzianum & SZMC 25728 & P. ostreatus, North Macedonia & MZ754499 & MZ773444 & MZ773455 & MZ773423 & Present study \\
\hline T. afroharzianum & SZMC 26672, KG10 & P. ostreatus, Serbia & MT876582 & MZ773435 & MZ773456 & MZ773414 & [15] \\
\hline T. atrobrunneum & SZMC 25744 & Lentinula edodes, Serbia & MZ754500 & MZ773440 & MZ773457 & MZ773419 & Present study \\
\hline T. atrobrunneum & SZMC 26673 & P. ostreatus, North Macedonia & MZ754501 & MZ773434 & MZ773458 & MZ773413 & Present study \\
\hline T. guizhouense & SZMC 22514 & P. ostreatus, Croatia & MZ754502 & MZ773448 & MZ773459 & MZ773427 & Present study \\
\hline T. guizhouense & SZMC 25749, T58 & L. edodes, Serbia & MT876594 & MZ773439 & MZ773460 & MZ773418 & [15] \\
\hline T. guizhouense & SZMC 25750, T59 & L. edodes, Serbia & MT876595 & MZ773438 & MZ773461 & MZ773417 & [15] \\
\hline T. guizhouense & SZMC 26669 & P. ostreatus, Serbia & MZ754503 & MZ773437 & MZ773462 & MZ773416 & Present study \\
\hline T. harzianum & SZMC 1764, C08 & Agaricus bisporus, Hungary & MZ754504 & MZ773453 & MZ773463 & MZ773432 & [15] \\
\hline T. harzianum & SZMC 1814, C22 & A. bisporus, Hungary & MZ754505 & MZ773452 & MZ773464 & MZ773431 & [24] \\
\hline T. harzianum & SZMC 1844 & A. bisporus, Croatia & MZ754506 & MZ773451 & MZ773465 & MZ773430 & Present study \\
\hline T. harzianum & SZMC 1848 & A. bisporus, Croatia & MZ754507 & MZ773450 & MZ773466 & MZ773429 & Present study \\
\hline T. harzianum & SZMC 25729 & P. ostreatus, North Macedonia & MZ754508 & MZ773443 & MZ773467 & MZ773422 & Present study \\
\hline T. harzianum & SZMC 25730 & P. ostreatus, North Macedonia & MZ754509 & MZ773442 & MZ773468 & MZ773421 & Present study \\
\hline T. pollinicola & SZMC 24399 & L. edodes, Hungary & MZ754510 & MZ773446 & MZ773469 & MZ773425 & Present study \\
\hline T. pollinicola & SZMC 24445 & L. edodes, Hungary & MZ754511 & MZ773445 & MZ773470 & MZ773424 & Present study \\
\hline T. simmonsii & SZMC 24248 & L. edodes, Hungary & MZ754512 & MZ773447 & MZ773471 & MZ773426 & Present study \\
\hline T. simmonsii & SZMC 25740 & L. edodes, Serbia & MZ754513 & MZ773441 & MZ773472 & MZ773420 & Present study \\
\hline T. simmonsii & SZMC 26671 & P. ostreatus, Serbia & MZ754514 & MZ773436 & MZ773473 & MZ773415 & Present study \\
\hline T. simmonsii & SZMC 26674 & P. ostreatus, North Macedonia & MZ754515 & MZ773433 & MZ773474 & MZ773412 & Present study \\
\hline T. aggressivum f. aggressivum & SZMC 23834 & A. bisporus, Hungary & $\mathrm{nr}$ & $\mathrm{nr}$ & $\mathrm{nr}$ & $\mathrm{nr}$ & [13] \\
\hline T. pleuroticola & SZMC 23033, TUCIM 2104 & P. ostreatus, Hungary & $\mathrm{nr}$ & $\mathrm{nr}$ & $\mathrm{nr}$ & $\mathrm{nr}$ & [25] \\
\hline T. reesei & SZMC 22614, TUCIM 917 & $\mathrm{nr}$ & $\mathrm{nr}$ & $\mathrm{nr}$ & $\mathrm{nr}$ & $\mathrm{nr}$ & [48] \\
\hline
\end{tabular}

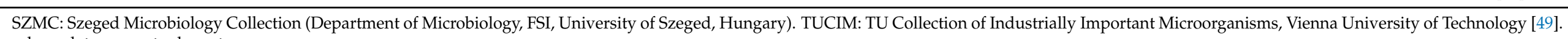
nd: no data. nr: not relevant. 
Trichoderma isolates were identified at the species level by the sequence analysis of the internal transcribed spacer (ITS) 1 and 2 regions of the ribosomal DNA, as well as fragments of the translation elongation factor 1-alpha (tef1), calmodulin (cal1) and RNA polymerase B subunit II ( $r p b 2)$ genes. The isolates were grown on PDA plates covered by cellophane membrane for 1 day at $25^{\circ} \mathrm{C}$, then genomic DNA was extracted from the harvested fresh mycelia using an E.Z.N.A. ${ }^{\circledR}$ Fungal DNA Mini Kit (Omega BIOTEK, Norcross, GA, USA), following the instructions of the manufacturer. Amplification and sequencing were performed as described by Hatvani et al. [50]. Multiple sequence alignments were made by MAFFT v7.312 [51], using the E-INS-i option. The dataset was partitioned to exons and introns in the case of call and tef1 sequences, while the ITS dataset was partitioned by ribosomal and internal transcribed spacer region. On the concatenated dataset, the best fitting model for each partition (Table 2) was selected by using ModelTest-NG v0.1.4 [52], based on the corrected Akaike information criterion (AICc). Maximum likelihood analysis was carried out by RAxML-NG v0.9.0 [53], with 1000 tbootstrap replicates. The corresponding sequences of the type strains of closely related Trichoderma species were used as reference based on recent taxonomic studies in connection with the THSC $[39,54]$.

Table 2. Best fit evolutionary models selected by ModelTest-NG.

\begin{tabular}{cc}
\hline Genomic Region & Selected Model \\
\hline cal1 intron & TPM1uf + G4 \\
\hline cal1 exon & TIM1 + G4 \\
\hline ribosomal region & TPM1uf + G4 \\
\hline internal transcribed spacer & TPM2uf + G4 \\
\hline$r p b 2$ & $\mathrm{GTR}+\mathrm{G} 4$ \\
\hline tef1 intron & $\mathrm{TIM} 2+\mathrm{G} 4$ \\
\hline tef1 exon & $\mathrm{TIM} 1+\mathrm{G} 4$ \\
\hline
\end{tabular}

A set of isolates sufficiently representing each detected species, host mushrooms and geographical locations was selected for the subsequent analyses based on the results of species identification.

The aggressiveness of the Trichoderma strains towards their host mushrooms was tested using in vitro confrontation assays. The protocol of Szekeres et al. [55], adapted to mushroom pathogenic Trichoderma strains [56] was applied with minor modifications. Agar discs (5 mm in diameter) cut from the growing front of the mushroom (A. bisporus SZMC 23395, P. ostreatus SZMC 23392, L. edodes SZMC 24442) colonies were inoculated onto PDA medium at a distance of $3 \mathrm{~cm}$ from the edge of the Petri plates $(9 \mathrm{~cm}$ in diameter). Trichoderma isolates were inoculated on the plates at $3 \mathrm{~cm}$ from the center of the mushroom colony in the same way after 7,3 and 3 days of incubation at $25^{\circ} \mathrm{C}$ in the case of $A$. bisporus, P. ostreatus and L. edodes, respectively. The non-mycoparasitic T. reesei E.G. Simmons SZMC 22614 strain was used as negative control, while isolates T. aggressivum f. aggressivum SZMC 23834 and T. pleuroticola SZMC 23033 were used in the case of $A$. bisporus, as well as $P$. ostreatus and L. edodes, respectively, as positive controls. The experiments were carried out in 2 replicates. The plates were photographed after 7 days of co-cultivation at $25{ }^{\circ} \mathrm{C}$, and the pictures were processed by the IrfanView v3.95 software. Aggressivity index (AI, \%) values were calculated from the areas occupied by the fungal colonies, using a previously developed image-analysis-based biocontrol index (BCI) assessment method [55,56], according to the following formula (1).

$\mathrm{AI}=$ area covered by the fungal pathogen/total covered area (pathogen and mushroom) $\times 100$

The susceptibility of the isolates to the two commercial fungicides authorized for mushroom cultivation in Europe, Harvinta (BASF S.E., Ludwigshafen, Germany; active 
ingredient: metrafenone $500 \mathrm{~g} / \mathrm{L}$ ) and Sporgon 50 WP (BASF Agro B.V., Zürich Branch, Switzerland; active ingredient: prochloraz $461 \mathrm{~g} / \mathrm{kg}$ ) [15] was examined on PDA medium amended with the fungicides. The effect of Harvinta and Sporgon 50 WP on mycelial growth was tested at 16, 8, 4, 2 and $1 \mathrm{mg} / \mathrm{L}$ concentrations, compared to the controls containing no fungicide. The Trichoderma strains were inoculated to the center of the plates as described above in 3 replicates. After 7 days of incubation at $25^{\circ} \mathrm{C}$, colony radius values were measured, and the rate of growth inhibition (GI, \%) was calculated using the formula below (2), where $r_{f}$ is the radius of colonies that appeared in the presence of the fungicides at different concentrations, while $r_{c}$ is the colony radius values measured on the control plates.

$$
\mathrm{GI}=100-\left(\mathrm{r}_{\mathrm{f}} / \mathrm{r}_{\mathrm{c}} \times 100\right)
$$

The statistical analysis of the obtained data was performed using the software $\mathrm{R}$ (version 4.0.3) [57] and RStudio Desktop (version 1.3.1093) [58]. The effect of the fungicide in different concentrations on fungal growth was analyzed by one-way ANOVA. Assumptions for parametric tests as normal distribution of the residuals and homoscedasticity (similar variances in all groups) were checked before applying statistical test. The variants not corresponding to the mentioned assumptions for parametric tests were analyzed using non-parametric alternative for ANOVA Kruskal-Wallis test. Each significant ANOVA result $(p<0.05)$ was subjected further to post-hoc pair-wise comparisons (Tukey's HSD (honestly significant difference) test). Unless specified, the data are presented as means of 3 replicates \pm standard deviation (SD).

\section{Results}

\subsection{Species Identification of Green Mould Agents}

A total of 21 Trichoderma strains isolated from specimens showing green mould symptoms at the growing facilities of A. bisporus, P. ostreatus and L. edodes from different European countries was examined in the study. On the basis of their ITS sequences, they were classified to the Trichoderma harzianum species complex (THSC), however, the subsequent multilocus sequence typing (MLST) analysis of the ITS, tef1, cal1 and rpb2 sequences of the isolates revealed various species (Figure 1). T. harzianum sensu stricto was the only species found to be associated with $A$. bisporus both in Hungary and Croatia, and it was also detected at a North Macedonian P. ostreatus growing farm. The samples of both oyster mushroom and shiitake appeared to be inhabited by T. atrobrunneum, T. guizhouense and T. simmonsii in various countries. T. afroharzianum was found to prefer the conditions of $P$. ostreatus cultivation regardless of geographical location, while T. pollinicola was detected exclusively at a Hungarian farm producing L. edodes (Table 1). 


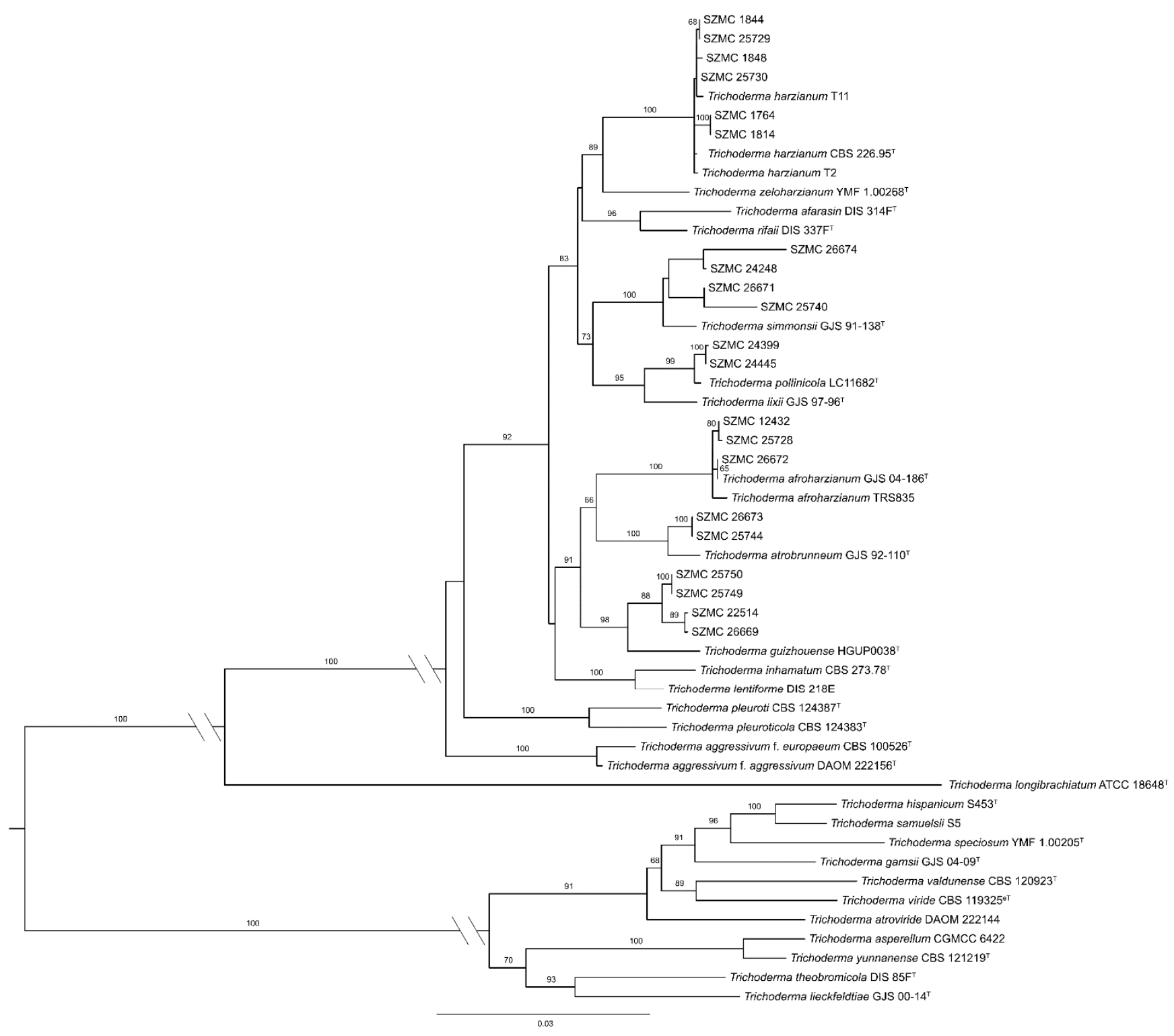

Figure 1. Maximum likelihood phylogenetic analysis of Trichoderma strains isolated from mushroom growing facilities based on the concatenated translation elongation factor 1-alpha (tef1), internal transcribed spacer (ITS), second largest subunit of RNA polymerase II (rpb2), and calmodulin (cal1) sequences. T = ex-type, eT = ex-epitype. Numbers above branches are bootstrap values. Only values higher than $70 \%$ are shown.

\subsection{Antagonistic Potential of Trichoderma Isolates against Cultivated Mushrooms In Vitro}

The antagonistic potential of the Trichoderma isolates towards their corresponding host mushrooms was tested using dual plate assays, and the results are shown in Table 3. Aggressiveness was considered as high, moderate and low if AI values were $>85,60-85$ and $<60$, respectively. Button mushroom was devastated by the examined T. harzianum strains (AI: 98.67 and 100.00), similarly to T. aggressivum f. aggressivum (AI: 100.00), but interestingly, the mushroom showed the same level of susceptibility to the non-mycoparasitic $T$. reesei as well. Likewise, both T. simmonsii and T. pollinicola could completely overgrow the colony of shiitake (AI: 100.00), while it appeared to be less susceptible to T. guizhouense (AI: 57.58) (Figure 2). Surprisingly, higher AI values were observed in the case of T. reesei than the pathogenic T. pleuroticola (AI: 80.80 and 73.15, respectively). Oyster mushroom also proved to be highly susceptible to the examined T. simmonsii isolates (AI: 87.65 and 88.70 ), but remarkable growth inhibition was caused by T. guizhouense and T. harzianum as well. In contrast, moderate resistance to T. afroharzianum was observed. 
Table 3. Aggressivity index (AI) values of Trichoderma strains confronted with cultivated mushrooms (means of 2 replicates \pm standard deviations).

\begin{tabular}{|c|c|c|c|}
\hline \multirow{2}{*}{ Trichoderma Strains } & \multicolumn{3}{|c|}{ AI (\%) } \\
\hline & Button Mushroom & Oyster Mushroom & Shiitake \\
\hline T. afroharzianum SZMC 12432 & - & $80.90 \pm 1.22$ & - \\
\hline T. afroharzianum SZMC 25728 & - & $83.84 \pm 0.98$ & - \\
\hline T. afroharzianum SZMC 26672 & - & $80.97 \pm 2.81$ & - \\
\hline T. atrobrunneum SZMC 25744 & - & - & $81.99 \pm 1.87$ \\
\hline T. atrobrunneum SZMC 26673 & - & $81.90 \pm 0.00$ & - \\
\hline T. guizhouense SZMC 22514 & - & $87.33 \pm 2.45$ & - \\
\hline T. guizhouense SZMC 25749 & - & - & $57.58 \pm 1.92$ \\
\hline T. guizhouense SZMC 26669 & - & $85.67 \pm 1.37$ & - \\
\hline T. harzianum SZMC 1764 & $98.67 \pm 1.15$ & & - \\
\hline T. harzianum SZMC 1844 & $100.00 \pm 0.00$ & - & - \\
\hline T. harzianum SZMC 25730 & - & $86.44 \pm 0.78$ & - \\
\hline T. pollinicola SZMC 24399 & - & - & $100.00 \pm 0.00$ \\
\hline T. simmonsii SZMC 24248 & - & - & $100.00 \pm 0.00$ \\
\hline T. simmonsii SZMC 25740 & - & & $100.00 \pm 0.00$ \\
\hline T. simmonsii SZMC 26671 & - & $88.70 \pm 1.67$ & \\
\hline T. aggressivum f. aggressivum SZMC 23834 & $100.00 \pm 0.00$ & - & - \\
\hline T. pleuroticola SZMC 23033 & - & $87.83 \pm 1.41$ & $73.15 \pm 1.61$ \\
\hline T. reesei SZMC 22614 & $100.00 \pm 0.00$ & $82.66 \pm 0.00$ & $80.80 \pm 2.11$ \\
\hline
\end{tabular}

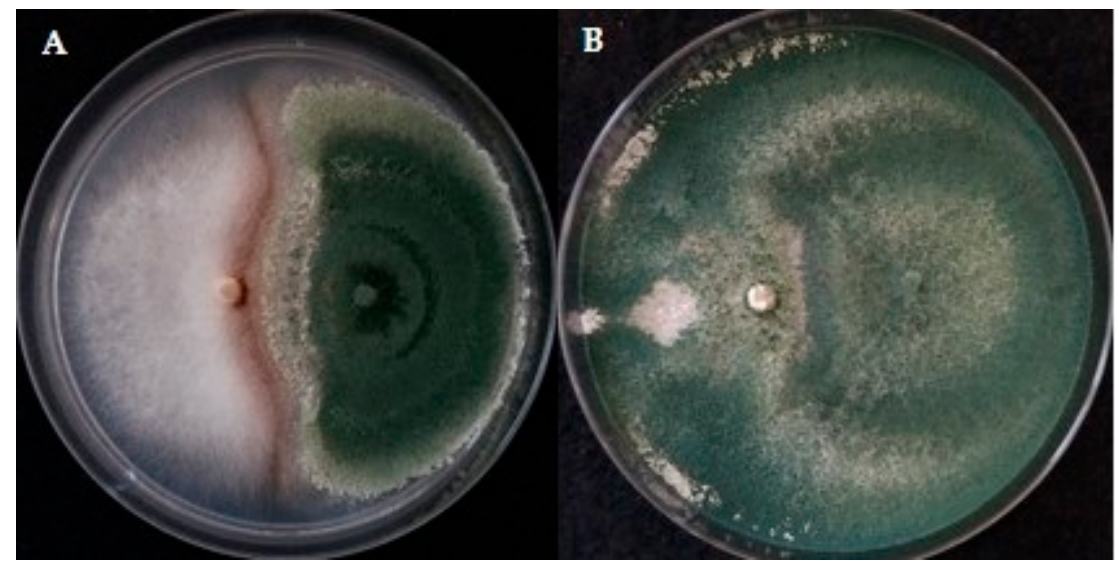

Figure 2. In vitro confrontation of Lentinula edodes (left) and Trichoderma isolates (right). (A) T. guizhouense SZMC 25749, (B) T. simmonsii SZMC 24248.

\subsection{Influence of Commercial Fungicides on Mycelial Growth}

The influence of the commercial fungicides prochloraz and metrafenone on the mycelial growth of the green mould agents was tested using the macrodilution method, the results are presented as the rate of growth inhibition (GI, \%) (Tables 4 and 5). Prochloraz could effectively inhibit the growth of the majority of the examined Trichoderma isolates at low concentration $(2-16 \mathrm{mg} / \mathrm{L}$, with no significant differences $(p>0.05))$, however, certain $T$. simmonsii strains showed tolerance to the fungicide, being able to grow remarkably even in the presence of the substance at the highest tested concentration $(16 \mathrm{mg} / \mathrm{L})$ as compared to the rest of the isolates $(p<0.05)$ (Table 4$)$. Although metrafenone was able to substantially inhibit 
the growth of certain Trichoderma strains (T. atrobrunneum SZMC 26673, T. simmonsii SZMC 26674 and SZMC 25740, T. guizhouense SZMC 25749) at 2-16 mg/L compared to other isolates $(p<0.05)$, the vast majority of the examined strains were just moderately affected by this fungicide, as it was not able to prevent their growth without significant differences between the tested concentration values, including the highest dose $(16 \mathrm{mg} / \mathrm{L}, p>0.05)$ (Table 5).

Table 4. Inhibitory effect of prochloraz on the mycelial growth of Trichoderma strains isolated from mushroom production (GI, \%).

\begin{tabular}{|c|c|c|c|c|c|c|c|}
\hline \multirow{2}{*}{ Trichoderma Strains } & \multicolumn{7}{|c|}{ Prochloraz (mg/L) } \\
\hline & 16 & 8 & 4 & 2 & 1 & 0.5 & 0.25 \\
\hline T. afroharzianum SZMC 12432 & $100.00 \pm 0.00$ & $100.00 \pm 0.00$ & $100.00 \pm 0.00$ & $97.31 \pm 2.33$ & $94.63 \pm 1.16$ & $91.27 \pm 2.33$ & $75.17 \pm 5.07$ \\
\hline T. afroharzianum SZMC 25728 & $100.00 \pm 0.00$ & $100.00 \pm 0.00$ & $100.00 \pm 0.00$ & $100.00 \pm 0.00$ & $96.55 \pm 3.16$ & $95.86 \pm 0.00$ & $78.62 \pm 1.20$ \\
\hline T. afroharzianum SZMC 26672 & $100.00 \pm 0.00$ & $96.72 \pm 5.68$ & $93.44 \pm 5.68$ & $96.72 \pm 5.68$ & $88.52 \pm 7.51$ & $96.72 \pm 5.68$ & $62.30 \pm 12.38$ \\
\hline T. atrobrunneum SZMC 25744 & $100.00 \pm 0.00$ & $89.91 \pm 4.37$ & $92.44 \pm 4.37$ & $84.03 \pm 2.91$ & $65.55 \pm 5.25$ & $71.43 \pm 2.91$ & $15.12 \pm 5.83$ \\
\hline T. atrobrunneum SZMC 26673 & $100.00 \pm 0.00$ & $93.14 \pm 1.70$ & $87.25 \pm 3.40$ & $88.24 \pm 5.10$ & $77.45 \pm 6.12$ & $78.43 \pm 1.70$ & $19.61 \pm 7.40$ \\
\hline T. guizhouense SZMC 22514 & $95.24 \pm 3.72$ & $96.43 \pm 4.72$ & $93.75 \pm 3.79$ & $94.64 \pm 3.09$ & $80.36 \pm 3.09$ & $80.35 \pm 6.44$ & $33.93 \pm 0.00$ \\
\hline T. guizhouense SZMC 25749 & $95.56 \pm 7.70$ & $88.89 \pm 3.85$ & $86.67 \pm 0.00$ & $91.11 \pm 7.70$ & $80.00 \pm 11.55$ & $84.45 \pm 16.78$ & $57.78 \pm 10.18$ \\
\hline T. guizhouense SZMC 26669 & $95.58 \pm 0.96$ & $91.16 \pm 0.95$ & $90.61 \pm 0.95$ & $85.08 \pm 1.66$ & $75.14 \pm 8.77$ & $79.56 \pm 4.17$ & $37.57 \pm 4.17$ \\
\hline T. harzianum SZMC 1764 & $100.00 \pm 0.00$ & $100.00 \pm 0.00$ & $100.00 \pm 0.00$ & $100.00 \pm 0.00$ & $96.53 \pm 6.02$ & $100.00 \pm 0.00$ & $84.03 \pm 1.21$ \\
\hline T. harzianum SZMC 1844 & $100.00 \pm 0.00$ & $100.00 \pm 0.00$ & $100.00 \pm 0.00$ & $100.00 \pm 0.00$ & $95.58 \pm 1.54$ & $97.35 \pm 2.66$ & $78.76 \pm 0.00$ \\
\hline T. harzianum SZMC 25730 & $100.00 \pm 0.00$ & $100.00 \pm 0.00$ & $100.00 \pm 0.00$ & $99.28 \pm 1.25$ & $92.09 \pm 4.49$ & $95.68 \pm 5.71$ & $81.29 \pm 4.49$ \\
\hline T. pollinicola SZMC 24399 & $100.00 \pm 0.00$ & $97.87 \pm 3.68$ & $96.45 \pm 3.25$ & $88.65 \pm 1.23$ & $83.69 \pm 2.46$ & $82.27 \pm 1.23$ & $40.43 \pm 5.63$ \\
\hline T. simmonsii SZMC 24248 & $89.63 \pm 3.39$ & $88.89 \pm 0.00$ & $88.15 \pm 1.28$ & $82.22 \pm 4.45$ & $75.56 \pm 2.23$ & $71.11 \pm 3.85$ & $28.15 \pm 5.59$ \\
\hline T. simmonsii SZMC 25740 & $89.70 \pm 2.10$ & $83.63 \pm 6.30$ & $71.82 \pm 1.29$ & $64.24 \pm 4.20$ & $41.82 \pm 3.64$ & $50.30 \pm 11.69$ & $12.73 \pm 3.15$ \\
\hline T. simmonsii SZMC 26671 & $82.68 \pm 3.49$ & $82.12 \pm 1.93$ & $77.09 \pm 3.49$ & $59.22 \pm 10.10$ & $41.90 \pm 4.22$ & $51.40 \pm 6.71$ & $18.99 \pm 4.84$ \\
\hline T. simmonsii SZMC 26674 & $95.42 \pm 0.00$ & $95.42 \pm 2.29$ & $91.60 \pm 2.64$ & $87.02 \pm 1.32$ & $79.39 \pm 2.29$ & $82.44 \pm 4.77$ & $35.12 \pm 17.49$ \\
\hline
\end{tabular}

Table 5. Inhibitory effect of metrafenone on the mycelial growth of Trichoderma strains isolated from mushroom production (GI, \%).

\begin{tabular}{|c|c|c|c|c|c|c|c|}
\hline \multirow{2}{*}{ Trichoderma Strains } & \multicolumn{7}{|c|}{ Metrafenone (mg/L) } \\
\hline & 16 & 8 & 4 & 2 & 1 & 0.5 & 0.25 \\
\hline T. afroharzianum SZMC 12432 & $24.32 \pm 2.34$ & $31.09 \pm 5.73$ & $27.03 \pm 8.11$ & $18.92 \pm 7.02$ & $20.27 \pm 2.34$ & $22.98 \pm 5.73$ & $22.97 \pm 7.02$ \\
\hline T. afroharzianum SZMC 25728 & $27.63 \pm 2.28$ & $25.00 \pm 5.59$ & $22.37 \pm 6.03$ & $32.90 \pm 6.84$ & $30.26 \pm 2.27$ & $30.26 \pm 6.03$ & $32.89 \pm 3.95$ \\
\hline T. afroharzianum SZMC 26672 & $32.79 \pm 17.27$ & $38.53 \pm 10.43$ & $37.71 \pm 12.38$ & $37.71 \pm 19.88$ & $47.54 \pm 17.27$ & $45.90 \pm 9.84$ & $52.46 \pm 11.36$ \\
\hline T. atrobrunneum SZMC 25744 & $26.67 \pm 7.64$ & $25.00 \pm 8.66$ & $13.33 \pm 2.89$ & $20.00 \pm 5.00$ & $26.67 \pm 10.41$ & $13.33 \pm 10.41$ & $20.00 \pm 5.00$ \\
\hline T. atrobrunneum SZMC 26673 & $73.68 \pm 0.00$ & $45.61 \pm 8.04$ & $57.90 \pm 22.32$ & $59.65 \pm 13.24$ & $63.16 \pm 13.92$ & $43.86 \pm 3.04$ & $61.40 \pm 8.04$ \\
\hline T. guizhouense SZMC 22514 & $33.33 \pm 3.71$ & $34.57 \pm 2.14$ & $25.93 \pm 0.00$ & $30.87 \pm 5.66$ & $23.46 \pm 13.01$ & $28.40 \pm 4.27$ & $27.16 \pm 9.32$ \\
\hline T. guizhouense SZMC 25749 & $59.26 \pm 12.83$ & $62.96 \pm 23.13$ & $61.11 \pm 23.57$ & $59.26 \pm 12.83$ & $51.85 \pm 12.83$ & $44.44 \pm 0.00$ & $70.37 \pm 6.41$ \\
\hline T. guizhouense SZMC 26669 & $17.78 \pm 1.92$ & $15.56 \pm 1.93$ & $18.89 \pm 3.85$ & $15.56 \pm 1.93$ & $20.00 \pm 5.77$ & $24.45 \pm 3.85$ & $12.22 \pm 5.09$ \\
\hline T. harzianum SZMC 1764 & $21.82 \pm 11.36$ & $21.82 \pm 15.74$ & $15.46 \pm 19.28$ & $10.91 \pm 31.01$ & $5.45 \pm 3.15$ & $12.73 \pm 0.00$ & $5.45 \pm 3.15$ \\
\hline T. harzianum SZMC 1844 & $11.43 \pm 4.95$ & $27.14 \pm 4.29$ & $18.58 \pm 6.06$ & $11.43 \pm 2.48$ & $24.28 \pm 4.95$ & $21.43 \pm 8.92$ & $22.86 \pm 4.29$ \\
\hline T. harzianum SZMC 25730 & $27.85 \pm 3.80$ & $31.65 \pm 7.60$ & $24.05 \pm 0.00$ & $24.05 \pm 0.00$ & $29.12 \pm 4.39$ & $26.58 \pm 5.80$ & $22.79 \pm 5.80$ \\
\hline T. pollinicola SZMC 24399 & $26.15 \pm 4.62$ & $44.62 \pm 13.06$ & $23.08 \pm 2.66$ & $26.15 \pm 0.00$ & $27.69 \pm 5.33$ & $29.23 \pm 2.67$ & $26.15 \pm 4.62$ \\
\hline T. simmonsii SZMC 24248 & $31.51 \pm 6.28$ & $35.62 \pm 4.75$ & $35.62 \pm 4.75$ & $38.36 \pm 4.11$ & $39.73 \pm 6.28$ & $36.99 \pm 12.55$ & $36.99 \pm 2.37$ \\
\hline T. simmonsii SZMC 25740 & $52.78 \pm 6.37$ & $44.44 \pm 2.40$ & $50.00 \pm 5.90$ & $40.28 \pm 10.48$ & $38.89 \pm 6.36$ & $55.56 \pm 2.40$ & $36.11 \pm 18.79$ \\
\hline T. simmonsii SZMC 26671 & $10.12 \pm 8.77$ & $20.26 \pm 6.58$ & $7.59 \pm 4.39$ & $15.19 \pm 2.19$ & $6.33 \pm 5.80$ & $11.39 \pm 2.19$ & $10.13 \pm 5.80$ \\
\hline T. simmonsii SZMC 26674 & $50.00 \pm 10.20$ & $40.54 \pm 6.19$ & $40.54 \pm 11.70$ & $27.03 \pm 7.03$ & $25.68 \pm 6.19$ & $44.60 \pm 13.03$ & $33.79 \pm 11.70$ \\
\hline
\end{tabular}




\section{Discussion}

Green mould, attributed primarily to T. aggressivum, T. pleuroti and T. pleuroticola, leads to substantial losses in the worldwide mushroom industry [14]. Our study has revealed that a broad range of further species belonging to the Trichoderma harzianum species complex are also able to cause severe green mould symptoms in the growing facilities of different edible mushrooms. The exclusive presence of T. harzianum sensu stricto was shown in infested samples of button mushroom in Croatia, and it was also found in $A$. bisporus cultivation in Hungary, confirming the previous findings of Hatvani et al. [21,24]. Moreover, we detected the species in an oyster mushroom farm in North Macedonia as well. Originally T. aggressivum f. europaeum and T. aggressivum f. aggressivum [20] were recognized as biotypes Th2 and Th4 of T. harzianum, being responsible for Agaricus green mould in Europe and North America, respectively [17-19]. Green mould disease caused by T. harzianum, affecting different cultivated edible mushrooms (such as Pleurotus spp., A. bisporus, L. edodes, Flammulina velutipes (Curtis) Singer, Ganoderma lucidum (Curtis) P. Karst., Volvariella volvacea (Bull.) Singer and Calocybe indica Purkay. \& A. Chandra) has been reported in numerous studies even since then [26,28,34,59-65]. However, the Trichoderma isolates examined in the aforementioned studies were identified based on morphological characteristics, ITS or tef1 sequences. To ensure the precise differentiation of species within the THSC, the analysis of multiple molecular markers, such as cal1, rpb2 or chi18-5 (chitinase $18-5)$ sequences can be recommended $[38,39,47,54]$. Using a multilocus approach, Oskiera et al. [44] identified several members of the THSC, namely T. harzianum sensu stricto, $T$. cf. harzianum, T. atrobrunneum and T. simmonsii, in samples collected at Polish mushroom farms, while T. harzianum was found on A. bisporus in Turkey [66] and also in shiitake production in Korea [67]. In addition to T. harzianum, in green mould affected oyster mushroom samples we could recover strains of T. afroharzianum, T. atrobrunneum, T. guizhouense and T. simmonsii, while in shiitake production T. atrobrunneum, T. guizhouense, T. simmonsii and T. pollinicola were found. Our analysis resulted in the identification of the THSC isolates T58, T59 and KG10 [15] as T. guizhouense and T. afroharzianum, respectively. The occurrence of T. atrobrunneum, T. simmonsii and T. guizhouense in mushroom cultivation has already been documented $[44-46,68]$ however, to the best of our knowledge, T. afroharzianum and T. pollinicola have not been reported to cause mushroom green mould disease so far.

In vitro confrontation assays have revealed high aggressiveness of T. harzianum towards A. bisporus, similarly to T. aggressivum $\mathrm{f}$. aggressivum. The results are in agreement with previous findings $[21,25,64,69]$, which also documented the colonization of $A$. bisporus by T. harzianum in vitro, while in the study of Aydoğdu et al. [66] it was found to be less harmful to button mushroom than T. aggressivum $\mathrm{f}$. aggressivum both in vitro and in vivo. The mushroom showed high sensitivity to the non-mycoparasitic $T$. reesei as well, confirming the results obtained by Komoń-Zelazowska et al. [25]. The shiitake culture was entirely colonized by T. simmonsii and T. pollinicola, whereas T. guizhouense demonstrated considerably lower aggressiveness. In contrast, the artificial inoculation of shiitake fruiting bodies with T. guizhouense strains T58 and T59 led to the development of severe green mould symptoms [15]. Oyster mushroom was strongly antagonized by $T$. simmonsii, as well as by T. harzianum and T. guizhouense strains. The effect was similar to that of T. pleuroticola, a known Trichoderma pathogen of P. ostreatus $[21,25,45]$. Contrary to our observations, T. guizhouense did not show high pathogenicity to oyster mushroom in the study of Innocenti et al. [45]. In our experiments, T. afroharzianum appeared to be only moderately aggressive towards P. ostreatus, supporting the findings of Luković et al. [15].

In our study, the commercial fungicide metrafenone (Harvinta) showed inhibitory effect on the growth of the examined Trichoderma strains just to a certain degree, while according to Luković et al. [15] it could efficiently suppress green mould isolates belonging to the THSC, including T. guizhouense T58 and T. afroharzianum KG10, which may be due to the differences in the applied incubation temperature $\left(25\right.$ and $20^{\circ} \mathrm{C}$, respectively). In contrast, we found prochloraz (Sporgon $50 \mathrm{WP}$ ) to be highly successful in inhibiting the growth of the majority of the examined green mould agents, in accordance with previous 
observations $[15,21,45,64,70-72]$. Nevertheless, T. simmonsii isolates were able to grow even if the fungicide was applied in the highest concentration $(16 \mathrm{mg} / \mathrm{L})$.

Even if a fungicide proves to be efficient in controlling green mould disease, there is always a risk for the development of resistance to it in the causal agents. Therefore, there is an increasing demand for the development of alternative means of pathogen control, to be applied within the frames of integrated disease/pest management (IDM/IPM) strategies [73]. Basically, a good quality substrate may prevent the development of green mold infection [3]. In champignon cultivation, the pasteurization of compost and the use of wood as a building material of growing spaces resulted in minimal green mould infestation, high yields and the occurrence of a larger number of flushes [74,75]. Catlin et al. [75] suggested a six-hour treatment at $60{ }^{\circ} \mathrm{C}$ for pasteurization after the harvest. However, this method is not always effective: green mould has already been isolated from freshly pasteurized compost [76], as pathogens can survive for some time at $60{ }^{\circ} \mathrm{C}$, but it is also likely that this temperature cannot be reached in all parts of the substrate. In addition, sterilization of fungal substrates may promote the growth of Trichoderma due to a decrease in the natural microbiota in the substrate, which in turn increases the potential for Trichoderma colonization due to the lower frequency of competitive microbiota $[77,78]$. Controlling the $\mathrm{pH}$ of the casing material is also a possible method to treat green mould [79]. Attention should also be paid to the quality of construction sites used for mushroom growing. Contamination of green mould is more likely to persist on rougher surfaces such as concrete or wood than on smoother, glazed surfaces [80]. In L. edodes cultivation, the shiitake mycelium infected in the cultured bags became rotten, withered, yellow, and eventually perished, the surface of the breeding bags being covered with dark green fungal colonies. Above $20^{\circ} \mathrm{C}$, an incidence of almost $100 \%$ was found in some mushroom farms [35]. Wang et al. [34] reported that metabolites of different Trichoderma species inhibited the growth of L. edodes mycelium, and its hyphae were distorted and swollen in vitro. A number of Bacillus and Streptomyces isolates proved to be efficient in suppressing the growth of mushroom pathogenic Trichoderma strains [70-72,81,82]. Moreover, a broad range of plant extracts, essential oils and compost teas were also found to sufficiently inhibit different fungal pathogens of mushrooms, including Trichoderma species [73], suggesting the possibility of involving these agents in IPM approaches to successfully combat mushroom green mould disease.

\section{Conclusions}

The results of the present study indicate a widening spectrum of potential mushroom pathogenic Trichoderma species, as in addition to the known causal agents (T. aggressivum, $T$. pleuroti, T. pleuroticola), different members of the T. harzianum species complex, particularly T. harzianum and T. simmonsii, are also able to cause green mould disease in mushroom cultivation. According to our data, the infections can be efficiently controlled using different chemical fungicides, especially prochloraz, however, the development of alternative, biological means of pest management is highly recommended and encouraged.

Author Contributions: Conceptualization and methodology, L.H.; software, S.K. and A.S.; formal analysis, S.K.; investigation, H.A.; resources, R.B.; data curation, A.S.; writing-original draft preparation, H.A.; writing-review and editing, L.H., L.K. and C.V.; visualization, A.Z.; supervision, L.H.; project administration, L.K.; funding acquisition, L.K., C.V. All authors have read and agreed to the published version of the manuscript.

Funding: The research was financed by the HUNGARIAN GOVERNMENT and the EUROPEAN UNION within the frames of the SZÉCHENYI 2020 PROGRAMME through grant GINOP-2.2.1-152016-00006. H.A. was supported by the ÚNKP-20-3-NEW NATIONAL EXCELLENCE PROGRAM of the MINISTRY FOR INNOVATION AND TECHNOLOGY from the source of the NATIONAL RESEARCH, DEVELOPMENT AND INNOVATION FUND.

Institutional Review Board Statement: Not applicable.

Informed Consent Statement: Not applicable. 
Data Availability Statement: DNA sequences obtained during the present study are openly available in NCBI GenBank [83] under the provided accession numbers (Table 1).

Acknowledgments: Isolates originating from Serbia and North Macedonia were kindly provided by Ivana Potočnik (Institute of Pesticides and Environmental Protection, Belgrade, Serbia).

Conflicts of Interest: The authors declare no conflict of interest.

\section{References}

1. Royse, D.J.; Baars, J.; Tan, Q. Current overview of mushroom production in the world. In Edible and Medicinal Mushrooms: Technology and Applications; Zied, D.C., Pardo-Giménez, A., Eds.; John Wiley \& Sons: Chichester, UK, 2017; pp. 5-13. [CrossRef]

2. da Eira, A.F. Cultivo do Cogumelo Medicinal Agaricus blazei (Murrill) SS Heinemann ou Agaricus brasiliensis; Aprenda Fácil: Viçosa, Brazil, 2003; 398p.

3. Bellettini, M.B.; Fiorda, F.A.; Maieves, H.A.; Teixeira, G.L.; Ávila, S.; Hornung, P.S.; Júnior, A.M.; Ribani, R.H. Factors affecting mushroom Pleurotus spp. Saudi J. Biol. Sci. 2019, 26, 633-646. [CrossRef] [PubMed]

4. Grogan, H.M. Fungicide resistance among Cladobotryum spp.-Causal agents of cobweb disease of the edible mushroom Agaricus bisporus. Mycol. Res. 2000, 104, 357-364. [CrossRef]

5. Adie, B.; Grogan, H.; Archer, S.; Mills, P. Temporal and spatial dispersal of Cladobotryum conidia in the controlled environment of a mushroom growing room. Appl. Environ. Microbiol. 2006, 72, 7212-7217. [CrossRef]

6. McKay, G.J.; Egan, D.; Morris, E.; Scott, C.; Brown, A.E. Genetic and morphological characterization of Cladobotryum species causing cobweb disease of mushrooms. Appl. Environ. Microbiol. 1999, 65, 606-610. [CrossRef] [PubMed]

7. Berendsen, R.L.; Baars, J.J.P.; Kalkhove, S.I.C.; Lugones, L.G.; Wösten, H.A.N.A.B.; Bakker, P.A.H.M. Lecanicillium fungicola: Causal agent of dry bubble disease in white-button mushroom. Mol. Plant Pathol. 2010, 11, 585-595. [CrossRef] [PubMed]

8. Thao, L.D.; Binh, V.T.P.; Khanh, T.N.; Thanh, H.M.; Hien, L.T.; Anh, P.T.; Trang, T.T.T.; Dung, N.V.; Hoai, H.T. First report of Lecanicillium fungicola var. aleophilum infecting white-button mushroom in Vietnam. New Dis. Rep. 2020, 41, 23. [CrossRef]

9. Sharma, S.R.; Kumar, S. Studies on wet bubble disease of white button mushrooms (Agaricus bisporus) caused by Mycogone perniciosa. In Science and Cultivation of Edible Fungi, Proceedings of the 15th International Congress on the Science and Cultivation of Edible Fungi, Maastricht, The Netherlands, 15-19 May 2000; A.A. Balkema: Rotterdam, The Netherlands, 2000; pp. 569-575.

10. Bora, T.; Özaktan, H. Biological control of some important mushroom diseases in Turkey by fluorescent Pseudomonads. Mushroom Sci. 2000, 15, 30.

11. Sharma, V.P.; Singh, C. Biology and control of Mycogone perniciosa Magn. causing wet bubble disease of white button mushroom. J. Mycol. Plant Pathol. 2003, 33, 257-264.

12. Zhang, C.; Kakishima, M.; Xu, J.; Wang, Q.; Li, Y. The effect of Hypomyces perniciosus on the mycelia and basidiomes of Agaricus bisporus. Microbiology 2017, 163, 1273-1282. [CrossRef]

13. Hatvani, L.; Kredics, L.; Allaga, H.; Manczinger, L.; Vágvölgyi, C.; Kuti, K.; Geösel, A. First report of Trichoderma aggressivum f. aggressivum green mold on Agaricus bisporus in Europe. Plant Dis. 2017, 101, 1052. [CrossRef]

14. Kredics, L.; Naeimi, S.; Hatvani, L.; Vágvölgyi, C.; Cai, F.; Druzhinina, I.S.; Manczinger, L. 'The Good, the Bad and the Ugly' in the shades of green: The genus Trichoderma in the spotlight. Indian Phytopathol. 2021, 74, 403-411. [CrossRef]

15. Luković, J.; Milijašević-Marčić, S.; Hatvani, L.; Kredics, L.; Szúcs, A.; Vágvölgyi, C.; Duduk, N.; Vico, I.; Potočnik, I. Sensitivity of Trichoderma strains from edible mushrooms to the fungicides prochloraz and metrafenone. J. Environ. Sci. Health B 2021, 56, 54-63. [CrossRef]

16. Castle, A.; Speranzini, D.; Rghei, N.; Alm, G.; Rinker, D.; Bissett, J. Morphological and molecular identification of Trichoderma isolates on North American mushroom farms. Appl. Environ. Microbiol. 1998, 64, 133-137. [CrossRef] [PubMed]

17. Doyle, O.; Morris, E.; Clancy, K. Trichoderma green mould update. Irish Mushroom Rev. 1991, 3, 13-17.

18. Seaby, D.A. Infection of mushroom compost by Trichoderma species. Mushroom J. 1987, 179, 355-361.

19. Seaby, D.A. Further observations on Trichoderma. Mushroom J. 1989, 197, 147-151.

20. Samuels, G.J.; Dodd, S.L.; Gams, W.; Castlebury, L.A.; Petrini, O. Trichoderma species associated with the green mold epidemic of commercially grown Agaricus bisporus. Mycologia 2002, 94, 146-170. [CrossRef]

21. Hatvani, L.; Sabolić, P.; Kocsubé, S.; Kredics, L.; Czifra, D.; Vágvölgyi, C.; Kaliterna, J.; Ivić, D.; Đermić, E.; Kosalec, I. The first report on mushroom green mould disease in Croatia. Arh. Hig. Rada Toksikol. 2012, 63, 481-486. [CrossRef] [PubMed]

22. Park, M.S.; Bae, K.S.; Yu, S.H. Two new species of Trichoderma associated with green mold of oyster mushroom cultivation in Korea. Mycobiology 2006, 34, 111. [CrossRef]

23. Woo, S.; Di Benedetto, P.; Senatore, M.; Abadi, K.; Gigante, S.; Soriente, I.; Ferraioli, S.; Scala, F.; Lorito, M. Identification and characterization of Trichoderma species aggressive to Pleurotus in Italy. Zhejiang Univ. J. Agric. Life Sci. 2004, 30, 469-470.

24. Hatvani, L.; Antal, Z.; Manczinger, L.; Szekeres, A.; Druzhinina, I.S.; Kubicek, C.P.; Nagy, A.; Nagy, E.; Vágvölgyi, C.; Kredics, L. Green mold diseases of Agaricus and Pleurotus spp. are caused by related but phylogenetically different Trichoderma species. Phytopathology 2007, 97, 532-537. [CrossRef] [PubMed]

25. Komon-Zelazowska, M.; Bissett, J.; Zafari, D.; Hatvani, L.; Manczinger, L.; Woo, S.; Lorito, M.; Kredics, L.; Kubicek, C.P.; Druzhinina, I.S. Genetically closely related but phenotypically divergent Trichoderma species cause green mold disease in oyster mushroom farms worldwide. Appl. Environ. Microbiol. 2007, 73, 7415-7426. [CrossRef] [PubMed] 
26. Błaszczyk, L.; Siwulski, M.; Sobieralski, K.; Frużyńska-Jóźwiak, D. Diversity of Trichoderma spp. causing Pleurotus green mould diseases in Central Europe. Folia Microbiol. 2013, 58, 325-333. [CrossRef] [PubMed]

27. Woo, S.L.; Kubicek, C.P.; Druzhinina, I.S.; Vinale, F.; Cavallo, P.; Lorito, M. Characterization of Trichoderma species associated with the production of Pleurotus ostreatus in Italy. J. Plant Pathol. 2009, 91, 94.

28. Miyazaki, K.; Tsuchiya, Y.; Okuda, T. Specific PCR assays for the detection of Trichoderma harzianum causing green mold disease during mushroom cultivation. Mycoscience 2009, 50, 94-99. [CrossRef]

29. Kim, C.S.; Yu, S.H.; Nakagiri, A.; Shirouzu, T.; Sotome, K.; Kim, S.C.; Maekawa, N. Re-evaluation of Hypocrea pseudogelatinosa and H. pseudostraminea isolated from shiitake mushroom (Lentinula edodes) cultivation in Korea and Japan. Plant Pathol. J. 2012, 28, 341-356. [CrossRef]

30. Kim, C.S.; Shirouzu, T.; Nakagiri, A.; Sotome, K.; Maekawa, N. Trichoderma eijii and T. pseudolacteum, two new species from Japan. Mycol. Progr. 2013, 12, 739-753. [CrossRef]

31. Kim, C.S.; Shirouzu, T.; Nakagiri, A.; Sotome, K.; Nagasawa, E.; Maekawa, N. Trichoderma mienum sp. nov., isolated from mushroom farms in Japan. Antonie Van Leeuwenhoek 2012, 102, 629-641. [CrossRef]

32. Kim, J.Y.; Yun, Y.H.; Hyun, M.W.; Kim, M.H.; Kim, S.H. Identification and characterization of Gliocladium viride isolated from mushroom fly infested oak log beds used for shiitake cultivation. Mycobiology 2010, 38, 7. [CrossRef]

33. Jaklitsch, W.M. European species of Hypocrea part II: Species with hyaline ascospores. Fungal Divers. 2011, 48, 1-250. [CrossRef]

34. Wang, G.; Cao, X.; Ma, X.; Guo, M.; Liu, C.; Yan, L.; Bian, Y. Diversity and effect of Trichoderma spp. associated with green mold disease on Lentinula edodes in China. Microbiol. Open 2016, 5, 709-718. [CrossRef]

35. Cao, X.T.; Bian, Y.B.; Xu, Z.Y. First report of Trichoderma oblongisporum causing green mold disease on Lentinula edodes (shiitake) in China. Plant Dis. 2014, 98, 1440. [CrossRef] [PubMed]

36. Rifai, M.A. A Revision of the Genus Trichoderma; Mycological Papers; Commonwealth Mycological Institute: Richmond Keew, UK, 1969; Volume 116, pp. 1-56.

37. Chaverri, P.; Castlebury, L.A.; Samuels, G.J.; Geiser, D.M. Multilocus phylogenetic structure within the Trichoderma harzianum/Hypocrea lixii complex. Mol. Phylogenet. Evol. 2003, 27, 302-313. [CrossRef]

38. Chaverri, P.; Branco-Rocha, F.; Jaklitsch, W.; Gazis, R.; Degenkolb, T.; Samuels, G.J. Systematics of the Trichoderma harzianum species complex and the re-identification of commercial biocontrol strains. Mycologia 2015, 107, 558-590. [CrossRef] [PubMed]

39. Qiao, M.; Du, X.; Zhang, Z.; Xu, J.; Yu, Z. Three new species of soil-inhabiting Trichoderma from southwest China. MycoKeys 2018, 44, 63-80. [CrossRef] [PubMed]

40. Zhu, Z.-X.; Xu, H.-X.; Zhuang, W.-Y.; Li, Y. Two new green-spored species of Trichoderma (Sordariomycetes, Ascomycota) and their phylogenetic positions. MycoKeys 2017, 26, 61-75. [CrossRef]

41. Gu, X.; Wang, R.; Sun, Q.; Wu, B.; Sun, J.-Z. Four new species of Trichoderma in the Harzianum clade from northern China MycoKeys 2020, 73, 109-132. [CrossRef] [PubMed]

42. Kubicek, C.P.; Herrera-Estrella, A.; Seidl-Seiboth, V.; Martinez, D.A.; Druzhinina, I.S.; Thon, M.; Zeilinger, S.; Casas-Flores, S.; Horwitz, B.A.; Mukherjee, P.K.; et al. Comparative genome sequence analysis underscores mycoparasitism as the ancestral life style of Trichoderma. Genome Biol. 2011, 12, R40. [CrossRef]

43. Chaverri, P.; Samuels, G.J. Evolution of habitat preference and nutrition mode in a cosmopolitan fungal genus with evidence of interkingdom host jumps and major shifts in ecology. Evolution 2013, 67, 2823-2837. [CrossRef] [PubMed]

44. Oskiera, M.; Szczech, M.; Bartoszewski, G. Molecular identification of Trichoderma strains collected to develop plant growthpromoting and biocontrol agents. J. Hortic. Res. 2015, 23, 75-86. [CrossRef]

45. Innocenti, G.; Montanari, M.; Righini, H.; Roberti, R. Trichoderma species associated with green mould disease of Pleurotus ostreatus and their sensitivity to prochloraz. Plant Pathol. 2019, 68, 392-398. [CrossRef]

46. Grujić, M.; Dojnov, B.; Potočnik, I.; Atanasova, L.; Duduk, B.; Srebotnik, E.; Druzhinina, I.S.; Kubicek, C.P.; Vujčić, Z. Superior cellulolytic activity of Trichoderma guizhouense on raw wheat straw. World J. Microbiol. Biotechnol. 2019, 35, 194. [CrossRef]

47. Druzhinina, I.S.; Kubicek, C.P.; Komoń-Zelazowska, M.; Mulaw, T.B.; Bissett, J. The Trichoderma harzianum demon: Complex speciation history resulting in coexistence of hypothetical biological species, recent agamospecies and numerous relict lineages. BMC Evol. Biol. 2010, 10, 94. [CrossRef]

48. Atanasova, L.; Jaklitsch, W.M.; Komon-Zelazowska, M.; Kubicek, C.P.; Druzhinina, I.S. Clonal species Trichoderma parareesei sp. nov. likely resembles the ancestor of the cellulase producer Hypocrea jecorina/T. reesei. Appl. Environ. Microbiol. 2010, 76, 7259-7267. [CrossRef] [PubMed]

49. Druzhinina, I.S.; Komon-Zelazowska, M.; Kredics, L.; Hatvani, L.; Antal, Z.; Belayneh, T.; Kubicek, C.P. Alternative reproductive strategies of Hypocrea orientalis and genetically close but clonal Trichoderma longibrachiatum, both capable of causing invasive mycoses of humans. Microbiology 2008, 154, 3447-3459. [CrossRef]

50. Hatvani, L.; Homa, M.; Chenthamara, K.; Cai, F.; Kocsubé, S.; Atanasova, L.; Mlinaric-Missoni, E.; Manikandan, P.; Revathi, R.; Dóczi, I. Agricultural systems as potential sources of emerging human mycoses caused by Trichoderma: A successful, common phylotype of Trichoderma longibrachiatum in the frontline. FEMS Microbiol. Lett. 2019, 366, fnz246. [CrossRef] [PubMed]

51. Katoh, K.; Toh, H. Parallelization of the MAFFT multiple sequence alignment program. Bioinformatics 2010, 26, 1899-1900. [CrossRef] [PubMed]

52. Darriba, D.; Posada, D.; Kozlov, A.M.; Stamatakis, A.; Morel, B.; Flouri, T. ModelTest-NG: A new and scalable tool for the selection of DNA and protein evolutionary models. Mol. Biol. Evol. 2020, 37, 291-294. [CrossRef] 
53. Kozlov, A.M.; Darriba, D.; Flouri, T.; Morel, B.; Stamatakis, A. RAxML-NG: A fast, scalable and user-friendly tool for maximum likelihood phylogenetic inference. Bioinformatics 2019, 35, 4453-4455. [CrossRef]

54. Zhao, Y.Z.; Zhang, Z.F.; Cai, L.; Peng, W.J.; Liu, F. Four new filamentous fungal species from newly-collected and hive-stored bee pollen. Mycosphere 2018, 9, 1089-1116. [CrossRef]

55. Szekeres, A.; Leitgeb, B.; Kredics, L.; Manczinger, L.; Vágvölgyi, C. A novel, image analysis-based method for the evaluation of in vitro antagonism. J. Microbiol. Meth. 2006, 65, 619-622. [CrossRef]

56. Körmöczi, P.; Leitgeb, B.; Cseh, T.; Hatvani, L.; Manczinger, L.; Vágvölgyi, C.; Kredics, L. An image analysis-based method for the evaluation of the aggressivity of Trichoderma strains towards Pleurotus ostreatus. Acta Microbiol. Immunol. Hung. 2009, 56, 188-189.

57. R (Version 4.0.3). Available online: https://www.r-project.org (accessed on 12 October 2020).

58. RStudio Desktop (Version 1.3.1093). Available online: http:/ / www.rstudio.com (accessed on 23 September 2020).

59. Choi, I.Y.; Joung, G.T.; Ryu, J.; Choi, J.S.; Choi, Y.G. Physiological characteristics of green mold (Trichoderma spp.) isolated from oyster mushroom (Pleurotus spp.). Mycobiology 2003, 31, 139-144. [CrossRef]

60. Park, M.S.; Seo, G.S.; Bae, K.S.; Yu, S.H. Characterization of Trichoderma spp. associated with green mold of oyster mushroom by PCR-RFLP and sequence analysis of ITS regions of rDNA. Plant Pathol. J. 2005, 21, 229-236. [CrossRef]

61. Singh, S.K.; Sharma, V.P.; Sharma, S.R.; Kumar, S.; Tiwari, M. Molecular characterization of Trichoderma taxa causing green mould disease in edible mushrooms. Curr. Sci. 2006, 90, 427-431.

62. Kim, W.G.; Weon, H.Y.; Seok, S.J.; Lee, K.H. In vitro antagonistic characteristics of bacilli isolates against Trichoderma spp. and three species of mushrooms. Mycobiology 2008, 36, 266-269. [CrossRef]

63. Błaszczyk, L.; Popiel, D.; Chełkowski, J.; Koczyk, G.; Samuels, G.J.; Sobieralski, K.; Siwulski, M. Species diversity of Trichoderma in Poland. J. Appl. Genet. 2011, 52, 233-243. [CrossRef]

64. Kosanović, D.; Potočnik, I.; Duduk, B.; Vukojević, J.; Stajić, M.; Rekanović, E.; Milijašević-Marčić, S. Trichoderma species on Agaricus bisporus farms in Serbia and their biocontrol. Ann. Appl. Biol. 2013, 163, 218-230. [CrossRef]

65. Kim, J.Y.; Kwon, H.W.; Yun, Y.H.; Kim, S.H. Identification and characterization of Trichoderma species damaging shiitake mushroom bed-logs infested by Camptomyia pest. J. Microbiol. Biotechnol. 2016, 26, 909-917. [CrossRef]

66. Aydoğdu, M.; Kurbetli, İ.; Kitapçı, A.; Sülü, G. Aggressiveness of green mould on cultivated mushroom (Agaricus bisporus) in Turkey. J. Plant Dis. Prot. 2020, 127, 695-708. [CrossRef]

67. Kim, C.S.; Park, M.S.; Kim, S.C.; Maekawa, N.; Yu, S.H. Identification of Trichoderma, a competitor of shiitake mushroom (Lentinula edodes), and competition between Lentinula edodes and Trichoderma species in Korea. Plant Pathol. J. 2012, 28, 137-148. [CrossRef]

68. Sun, J. Fifteen fungicolous Ascomycetes on edible and medicinal mushrooms in China and Thailand. Asian J. Mycol. 2019, 2, 129-169. [CrossRef]

69. Goltapeh, M.E.; Danesh, Y.R. Pathogenic interactions between Trichoderma species and Agaricus bisporus. J. Agric. Technol. 2006, 2, 29-37.

70. Milijašević-Marčić, S.; Stepanović, M.; Todorović, B.; Duduk, B.; Stepanović, J.; Rekanović, E.; Potočnik, I. Biological control of green mould on Agaricus bisporus by a native Bacillus subtilis strain from mushroom compost. Eur. J. Plant Pathol. 2017, 148, 509-519. [CrossRef]

71. Šantrić, L.; Potočnik, I.; Radivojević, L.; Umiljendić, J.G.; Rekanović, E.; Duduk, B.; Milijašević-Marčić, S. Impact of a native Streptomyces flavovirens from mushroom compost on green mold control and yield of Agaricus bisporus. J. Environ. Sci. Health B 2018, 53, 677-684. [CrossRef] [PubMed]

72. Stanojević, O.; Berić, T.; Potočnik, I.; Rekanović, E.; Stanković, S.; Milijašević-Marčić, S. Biological control of green mould and dry bubble diseases of cultivated mushroom (Agaricus bisporus L.) by Bacillus spp. Crop Prot. 2019, 126, 104944. [CrossRef]

73. Gea, F.J.; Navarro, M.J.; Santos, M.; Diánez, F.; Carrasco, J. Control of fungal diseases in mushroom crops while dealing with fungicide resistance: A review. Microorganisms 2021, 9, 585. [CrossRef]

74. Peil, R.M.; Rossetto, E.A.; Pierobom, C.R.; Rocha, M.T. Desinfestação de composto para cultivo de cogumelo Agaricus bisporus (Lange) Imbach. Rev. Bras. Agrociência 1996, 2, 159-164.

75. Catlin, N.J.; Wuest, P.J.; Beyer, D.M. Green mold harbored by wood: Post-crop steaming and preservatives. Mushroom Sci. 2004, 16, 449-458.

76. Morris, E.; Harrington, O.; Doyle, O.P.E.; Clancy, K.J.C. Green mould disease-The study of survival and dispersal characteristics of the weed mould Trichoderma, in the Irish mushroom industry. In Science and Cultivation of Edible Fungi, Proceedings of the 15th International Congress on the Science and Cultivation of Edible Fungi, Maastricht, The Netherlands, 15-19 May 2000; A.A. Balkema: Rotterdam, The Netherlands, 2000; pp. 645-651.

77. Velázquez-Cedeño, M.; Mata, G.; Farnet, A.M.; Savoie, J.M. Estudio preliminar de la microflora bacteriana termotolerante de la pulpa de café y la paja de trigo con potencial de inhibición contra Trichoderma viride en el cultivo de Pleurotus spp. Rev. Mex. Micol. 2006, 22, 33-39.

78. Colavolpe, M.B.; Mejía, S.J.; Albertó, E. Efficiency of treatments for controlling Trichoderma spp. during spawning in cultivation of lignicolous mushrooms. Braz. J. Microbiol. 2014, 45, 1263-1270. [CrossRef] [PubMed]

79. Rinker, D.L.; Alm, G. Management of casing Trichoderma using fungicides. In Science and Cultivation of Edible and Medicinal Fungi: Mushroom Science XVII, Proceeding of the 17th Congress of the International Society for Mushroom Science, Cape Town, South Africa, 20-24 May 2008; South African Mushroom Farmers Association: Pretoria, South Africa, 2008; pp. 496-509. 
80. Abosriwil, S.O.; Clancy, K.J. A protocol for evaluation of the role of disinfectants in limiting pathogens and weed moulds in commercial mushroom production. Pest Manag. Sci. 2002, 58, 282-289. [CrossRef] [PubMed]

81. Chittihunsa, T.; Bangeekhan, E.; Wongsamitkul, N.; Subsomboon, T. Screening of Bacillus spp. suppressing the infection of Trichoderma sp. in mushroom cultivation. Curr. Appl. Sci. Technol. 2007, 7, 19-27.

82. Aydoğdu, M.; Sülü, S.M.; Kurbetli, İ.; Sülü, G. In vitro and in vivo biological control of the green mold using different bacteria in button mushroom cultivation. Egypt. J. Biol. Pest Control 2021, 31, 70. [CrossRef]

83. NCBI GenBank. Available online: https://www.ncbi.nlm.nih.gov/genbank/ (accessed on 25 November 2021). 